\title{
Historical 'Signposts' and Other Temporal Indicators in the Czech Lexicon
}

TOM DICKINS

\section{Introduction}

This article takes as its theme a phenomenon that is characteristic of, if by no means unique to, Czech language change: namely, the lexical 'signposting' of major historical periods and events. The use of the geographical metaphor of the 'signpost' to identify particular points in the development of society, and to indicate its ideological direction, seems apposite in view of the large number of expressions in Czech which serve to 'map' the historical development of the nation state. The term is not intended in the Saussurean sense of the 'sign', but certain aspects of semiotic theory are of relevance to the current discussion, if we are to assume a conventional interpretation of semantic change as an alteration in the relationship between meaning and name. ${ }^{1}$ Temporal indicators are primarily of importance symbolically, in that they highlight a radical break from the more immediate past, but they also form part of a cognitive framework or 'Narrative Template', to use Wertsch's terminology, which may render a return to the values of a former regime more problematic. ${ }^{2}$ In other words, they help to shape collective memory by (re)inventing tradition and by (re-)establishing continuity with a more distant past, to

Tom Dickins is a Senior Lecturer in the School of Law, Social Sciences and Communications at the University of Wolverhampton.

1 See, for example, Stephen Ullmann, The Principles of Semantics, 2nd edn, Oxford, 1957, p. 171.

${ }^{2}$ See J. V. Wertsch, 'Narrative Dialogicality and Narrative Templates in the Production of Official Collective Memory', in Voices of Collective Remembering, New York, 2002, chapter 5, pp. 87-116. 
draw on Hobsbawm's line of argument, ${ }^{3}$ and they (re)appropriate usage in order to right more recent historical 'wrongs'.

Historical signposts vary in their semantic scope and application, but they frequently share at least some of the following characteristics: 1) they have an iconic status in national historiography (which is qualitatively different from the status accorded to other significant historical events); 2) they are dynamic (in the sense that their meaning and referents change over time); 3) their interpretation and connotations are inherently variable (partly as a result of their dynamism); 4) they have an impact on other semantically related lexical items; 5) they tend to occur in fixed expressions, and 6) they are sufficiently well established to lend themselves to morphological adaptation.

A good example of a canonical phrase that meets the criteria of a lexical signpost is (státní) prevrat ([state] takeover or 'coup [d'état]'), which is found nearly a thousand times in its nominal form in the latest 100-million-word balanced reference corpus of written Czech, Korpus SYN 2010 , based mainly on texts from 2005 to $2009 .{ }^{4}$ Převrat may relate to any radical change, especially the seizure of state control, and can be difficult to render in English precisely because of its range of applications, but in a twentieth-century Czechoslovak context it was applied to four major historical episodes: 1) the establishment of the First Republic in 1918; 2) the overthrow of German rule in 1945; 3) the Communist takeover in 1948, and 4) the Velvet Revolution in 1989. It is sufficient merely to qualify prevrat by using the name of the appropriate month for it to switch referents; that is, ř́ijnový prevrat (October takeover [1918]) cited seven times in SYN 2010, květnový prevrat (May uprising [1945]) cited twenty-two times, Ú/únorový přvrat (February takeover [1948]) cited fifty-one times, and L/listopadový prevrat (November revolution [1989]) cited twenty-nine times. ${ }^{5}$ Derivatives spawned by prevrat include the adjective P/prevratný, recorded over 600 times in SYN 2010, and its older alternative prevratový, recorded eighteen times, the adverb prevratně, thirty-two citations, and the more marginal terms prevratník (putschist) and prevratnictví (putschism). Collocations

3 See Eric Hobsbawm, 'Introduction: Inventing Traditions', in Eric Hobsbawm and Terence Ranger (eds), The Invention of Tradition, Cambridge, 1983, pp. 1-14.

4 Český národní korpus, Prague <http://ucnk.ff.cuni.cz> [accessed 10 May 2011].

5 The use of months to denote historic events would appear to be especially prevalent in the languages of 'Eastern' Europe. Compare Russian oktiabr'skaia revolutsiia (occasionally also oktiabr'skii perevorot) (October revolution [in 1917]) and Polish przewrót majowy ([Józef Piłsudski's] May coup d'état [in 1926]). See Andrew Roberts, From Good King Wenceslas to the Good Soldier Švejk: A Dictionary of Czech Popular Culture, Budapest and New York, 2005, p. 131. 
include D/do prevratu (pre-takeover) seven citations, and P/po prevratu (or po prevratě in older usage) (post-takeover) 152 citations, which have in turn given rise to the adjectival forms doprevratový, not cited, and poprevratový, thirty-nine citations. ${ }^{6}$ P/po prevratu (po prevratě) represents more than one in eight of all the citations for prevrat in SYN 2010, and can generally be understood by historical context alone. As collocates of prevrat-, Po and po have noteworthy $\mathrm{t}$-scores of 5.711 and 10.88 , respectively, in the range from -1 to o.?

The occurrence of set phrases such as po prevratu (po převratě) is in itself unremarkable, in view of the sudden and dramatic shifts in political power that have taken place in the Czech-speaking lands, and the need to 'fix' defining moments in the history of the nation state. The Czechs, in common with all 'Eastern' Europeans, have experienced radical change and upheaval on several occasions within living memory. Unlike much of Western Europe, the eastern part of the continent has had to adjust repeatedly to new realities. As Judt puts it:

Whereas the West European dilemma was confined to a single set of unhappy memories located in the occupation years 1940-1944/45, the East Europeans have multiple analogous reference points: 1918-1921, $1938,1939,1941,1944,1945-1948,1956,1968$, and now 1989. Each of these moments in time means something different, and nearly always something contentious, to a different nation or ethnic group, or else to succeeding generations within the same group. ${ }^{8}$

It is not so much the existence of historical signposts that makes them deserving of more detailed and systematic analysis, but the frequency with which they recur, and the function that they perform in the lexicon. Temporal indicators such as po prevratu contribute to a specific semantic domain, which takes the form of a semi-hierarchical nomenclature of momentous historical referents, whose meaning is at least partly derived

6 Compare their more frequent synonyms P/predrevoluční (pre-revolutionary) sixtyseven citations, and P/porevoluční (post-revolutionary) 129 citations.

7 The $\mathrm{t}$-score is felt to be the most accurate measure of the predictability of co-occurrence where the lemma under consideration is not especially common. A t-score of 2 or more is considered to be statistically significant. See Geoff Barnbrook, Language and Computers, Edinburgh, 1996, pp. 97-100, and Susan Hunston, Corpora in Applied Linguistics, Cambridge, 2002, pp. 70-75. It should be noted that citations mentioned here and elsewhere may include a few examples which do not relate to Czech(oslovak) reality.

8 Tony Judt, 'The Past Is Another Country: Myth and Memory in Postwar Europe', Daedalus, 121, 1992, 4, pp. 83-118 (pp. 99-100). 
from their associations with contiguous lexical items. This domain is unusual in that it operates differently both on a synchronic and a diachronic plane, at both a private and a public level..$^{9}$ As will be shown later, prevrat is merely one of several examples of a specific type of 'composite name transfer', in which a widely recognized sense of a lexical item has subsequently been supplanted by a new sense. ${ }^{10}$

The main contribution of this study resides in the range of the examples cited and in the analysis of their uses, rather than in detailed consideration of the role of language-internal processes. Attention is paid both to onomasiological and semasiological questions (the names applied to, and the meanings attributed to, referents), as well as to the connections between semantically related lexical items. When a neologism or new meaning becomes established, the effect is felt not only on lexemes in the same semantic field, but also on the development of the lexicon as a whole. Lyons, summarizing the arguments of Jost Trier in the 1930s, says 'it is one of the major failings of traditional diachronic semantics that it sets out to catalogue the history of changes in the meanings of individual lexemes atomistically, or one by one, instead of investigating changes in the whole structure of the vocabulary as it has developed through time.. ${ }^{11}$ Trier may have overstated the extent to which lexical fields (Wortfelder) have clearly defined boundaries without gaps or overlaps, as well as the degree of the impact that any change to a part of the field has on its entire system, but his concern with the diachronic dimension of meaning was far-sighted. ${ }^{12}$ Kleparski, who is generally critical of linguists' lack of attention to lexical change over time, has acknowledged the utmost importance of Trier's methodological contribution to diachronic semantics, but has also noted with regret that Trier 'failed to produce any classificatory framework against which his interesting observations could be set'. ${ }^{13}$

Perhaps the most helpful general framework remains that of Stern, who identified seven classes of semantic change: 'substitution' (the effect of

9 The most comprehensive readily available source of private discourse is the subcorpus of the Czech National Corpus, KSK Dopisy [Private Correspondence Corpus], comprising 800,000 words taken from the transcriptions of 2,00o letters, but unfortunately it only covers the period from 1990 to 2004.

${ }^{10}$ Ullmann, The Principles of Semantics, p. 241.

${ }^{11}$ John Lyons, Semantics, vol. 1, Cambridge, 1991, p. 252.

${ }^{12}$ See Grzegorz A. Kleparski and Angela Rusinek, 'The Tradition of the Lexical Field and the Study of Lexical Semantic Change', Zeszyty Naukowe Uniwersytetu Rzeszowskiego, 47, Studia Anglica Resoviensia, 4, 2007, pp. 188-205 (p. 189) <http://www.univ.rzeszow.pl/ wfil/ifa/usar4/sar_v4_13.pdf> [accessed 14 June 2010].

${ }_{13}$ Grzegorz A. Kleparski, 'Twentieth Century Trends in Diachronic Semantics - A Retrospective View', Linguistica Silesiana, 7, 1985, pp. 109-20 (p. 119). 
external, non-linguistic factors), 'analogy' (the adoption of a new sense, by analogy, for example, with a shift in the use of a different part of speech), 'shortening' (such as the omission of a word from a compound phrase, or, in Czech, the use of univerbization), 'nomination' (the intentional transfer of a name from one referent to another, as in 'ox' to describe a powerful person), 'permutation' (a shift in use where a secondary meaning renders the primary meaning redundant) and 'adequation' (the adaptation of a meaning based on the subjective apprehension of an object, as in the use of 'leg' as part of a table). ${ }^{14}$ Of these seven categories, 'permutation' (which is basically composite name transfer in its purest form) and the external (non-linguistic) type of change - 'substitution' - would appear to be most germane to the present study.

The article begins with an overview of relevant contributions in the field of semiotics and semantics, with particular reference to connotation, the lability of meaning, and language as a mediator of reality. The second part looks in detail at the types of lexical sources available to the linguist, and highlights some of the difficulties associated with dictionary definitions. The subsequent section seeks to contextualize the lexical signpost, with specific reference to the pre-1918 era and to public holidays and 'significant' days. The study then considers in greater detail the historical waymarks of the First Republic, German rule and its aftermath, the rise and fall of Communism, and the return to parliamentary democracy.

\section{Semantic considerations}

Much of the traditional focus of semiotics has been on the relational aspects of meaning from a synchronic perspective. ${ }^{15}$ Space prohibits detailed consideration here of the different structural approaches to the creation of meaning, but it would be remiss not to mention in passing the centrality in semiotic theory of Saussure's and Peirce's typologies of signs. ${ }^{16}$ In the context of an essay on lexical variation in Czech, acknowledgement should also be given to the contribution of the Prague Linguistic Circle, especially vis-à-vis the social functions of language forms in everyday

\footnotetext{
${ }^{14}$ Gustaf Stern, Meaning and Change of Meaning, with Special Reference to the English Language, Göteborg, 1931, pp. 165-69.

${ }^{15}$ For an accessible general introduction to semiotics, see Daniel Chandler, Semiotics: the Basics, London, 2007.

${ }^{16}$ See, for example, Ferdinand de Saussure, Course in General Linguistics, London, 1960, edited by Charles Bally and Albert Sechehaye, in collaboration with Albert Reidlinger, translated by Wade Baskin; Charles S. Peirce, Collected papers: Volume V. Pragmatism and Pragmaticism, Cambridge, MA, 1934, and Sándor Hervey, 'A Background to Semiotics: Saussure and Peirce', in Semiotic Perspectives, London, 1982, pp. 9-37.
} 
communication. ${ }^{17}$ Amongst the smaller number of linguists who have paid attention to the historical development of meaning, Voloshinov arguably stands out for his work on the construction of signs in terms of what he and others perceived as the class struggle. ${ }^{18}$ Of greater relevance to this article, however, was the groundbreaking work of Hjelmslev, Barthes and others, who moved away from the treatment of signs as autonomous abstract concepts and emphasized instead the importance of connotation, or context-dependent meaning. ${ }^{19}$

The distinction between 'denotation' and 'connotation' is problematic. The former tends to be more overtly referential and deals with the primary, 'literal' or commonly accepted meaning of a lexical unit, whereas the latter relates principally to its transferred or secondary sense; or, in Chandler's words, to "the socio-cultural and "personal" associations (ideological, emotional, etc.) of the sign'. ${ }^{20}$ Leech argues that the boundary between conceptual (or denotative) meaning and connotative meaning is coincident with the "nebulous but crucial boundary between "language" and the "real world", and that connotative meaning is peripheral, relatively unstable, indeterminate and open-ended. ${ }^{21}$ The sceptical interpretation by many Czechs of the ideologically wooden language of the Communists, replete with terms such as kádrová politika (personnel management strategy), prověrkové rízení (screening procedures) and socialistickýzávazek (socialist obligation), highlights the extent to which connotative meaning can supplant (officially endorsed and promoted) denotative meaning in people's minds. ${ }^{22}$ As Stern succinctly expresses it, 'Meaning is essentially personal. ${ }^{23}$

Urdang has suggested that in many cases the principal meaning of a phrase is actually its 'connotative' meaning, and he has consequently appealed to fellow lexicographers to give higher priority to metaphor in

17 See, for example, Josef Vachek (in collaboration with J. Dubský), Dictionary of the Prague School of Linguistics, Amsterdam, 2003, translated by A. Klégr, P. Šaldová, M. Malá, J. Čermák and L. Dušková.

${ }^{18}$ For an English translation of Voloshinov's most influential work, see Valentin N. Voloshinov, Marxism and the Philosophy of Language, New York, 1973, translated by Ladislav Matejka and I. R. Titunik.

${ }^{19}$ See Louis Hjelmslev, Prolegomena to a Theory of Language, Madison, 1961, translated by Francis J. Whitfield, and Roland Barthes, Elements of Semiology, London, 1967, translated by Annette Lavers and Colin Smith.

${ }^{20}$ Chandler, Semiotics: The Basics, p. 138.

${ }^{21}$ Geoffrey Leech, Semantics, Harmondsworth, 1981, p. 15.

${ }^{22}$ For a comprehensive non-corpus-based analysis of the lexicon of Communism, see Jiř́i Pruša, Abeceda realného socialismu, Prague, 2011.

${ }^{23}$ Stern, Meaning and Change of Meaning, p. 41. 
dictionaries. ${ }^{24}$ While Urdang's point is not without substance, it may be more helpful to think of secondary sense (where the metaphorical or metonymic meaning has come to enjoy widespread acceptance) as 'nonbasic denotative meaning' rather than as 'connotative meaning'. Ayto has maintained that any semantic features that might be considered connotational are, by virtue of being 'meaning components' of an utterance, part of the denotation of that utterance, and that connotation must thus have become denotation if it is to qualify for dictionary entry. ${ }^{25}$ The problem of distinguishing systematically between connotative meaning which contributes clearly to denotative meaning, and connotative meaning as a purely real-world phenomenon, is repeatedly borne out by the Czech lexicon.

Amongst the more noteworthy examples of semantic extension from basic to non-basic denotative meaning in modern Czech history are Hrad ([Prague] Castle > [transferred meaning] President Tomáš Garrigue Masaryk, Edvard Beneš and their circle [in the First Republic, 191838]), Mnichov (Munich > the Munich Agreement in September 1938), and normalizace/normalisace (normalization $>$ the policies adopted by President Gustáv Husák to reverse the reforms of the Prague Spring and reimpose hard-line Communist rule), of which the last two are discussed later. The metaphorization of a word may sometimes make it difficult to differentiate its primary sense from its secondary sense, as was the case under Communism with brigáda ([military] brigade, work group; temporary/seasonal job), kádry (personnel; [Party] stalwarts) and, possibly, rudý (red; Communist [often used pejoratively]). ${ }^{26}$ Other problematic polysemes may occur as a result of borrowing from a closely related language, as in, say, družba (traditionally 'a best man', but subsequently used in the sense of 'friendship [at an institutional level]', from Russian druzhba).

The more recent focus by post-structuralists on the lability and inconsistency of meaning has served to place even greater emphasis on individual interpretation and the systems of knowledge that lead to that

${ }^{24}$ L. Urdang, 'Meaning: Denotative, Connotative, Allusive', in R. R. King (general ed.), Dictionaries and their Users: Papers from the 1978 B.A.A.L. Seminar on Lexicography, Exeter Linguistic Studies, vol. 4, Exeter, 1979, pp. 47-52.

${ }^{25}$ J. R. Ayto, 'On Specifying Meaning: Semantic Analysis and Dictionary Definitions', in R. R. K. Hartmann (ed.), Lexicography: Principles and Practice, London, 1983, pp. 89-98 (pp. 95-98).

${ }_{26}$ The terms brigáda and rudý are still widely used in Czech with their transferred meanings. 
interpretation, rather than on the underlying structures of language and the user's intended meaning. ${ }^{27}$ Social constructionists share the poststructuralist interest in the subjectivity of meaning, and argue, from a psychological perspective, that questions of power, as reflected in language conventions and norms, ultimately determine how we see ourselves and the world around us. ${ }^{28}$ Young, in his important study of totalitarian language, has similarly claimed, albeit from a different psychological viewpoint, that the way we interpret reality is dependent on the language we use. His argument, drawing on Humboldt and others, is that the naming process endows the world with significance, but that as soon as we name something, this throws up a barrier between ourselves and the world which distorts the object or reality that the name supposedly represents. In other words, the nearest we can get to reality is the conceptual sphere or Zwischenwelt which mediates it. ${ }^{29}$

In terms of his contribution to philology, Humboldt is perhaps best known for his linguistic relativism, which asserted a strong relationship between language and thought. His work was in some ways a precursor to the better known Sapir-Whorf hypothesis which, in its generally preferred weaker version, holds that language influences our perception of reality (rather than necessarily determining that perception). ${ }^{30}$ The current article broadly accepts the legitimacy of the relativist approach, while also acknowledging that individual interpretations of meaning vary widely. It proceeds from the premise that, although objectivity may be unattainable and meaning may be fuzzy and 'essentially personal', the existence of certain realities and their officially approved representation is so well attested that it does not require further ontological investigation. It may not be possible to arrive at a universally agreed definition for any lexical item, and it is certainly not possible to account for all the theoretical connotations of that expression, but it would seem legitimate to talk about the principal denotation(s) of a phrase at (or relating to) a given point or period in history.

Stern argues that, leaving aside emotional 'non-symbolic' elements, the three determinants of cognitive (or noetic) meaning are 1) the objective

\footnotetext{
27 See, for example, Madan Sarup, An Introductory Guide to Post-Structuralism and Postmodernism, Harlow, 1993.

${ }^{28}$ See, for example, Vivien Burr, An Introduction to Social Constructionism, London and New York, 1995.

${ }^{29}$ John Wesley Young, Totalitarian Language: Orwell's Newspeak and its Nazi and Communist Antecedents, Charlottesville, VA and London, 1991, pp. 14-15.

30 See, for example, James W. Underhill, Humboldt, Worldview and Language, Edinburgh, 2009, and Paul Kay and Kempton Willet, 'What is the Sapir-Whorf Hypothesis?', American Anthropologist, 86, 1984, 1, pp. 65-79.
} 
reference ('the one element of meaning that cannot disappear'); 2) the subjective apprehension ('the referent generally has more than one attribute or characteristic'), and 3) the traditional range ('The range of the word is either the totality of referents that can be denoted by it, the referential range, or the totality of meanings that it can express, the semantic range'). ${ }^{31}$ This study is interested in all three, with particular reference to their relevance for the development of the lexicon over time. Kleparski and Rusinek, in their discussion of field theory, note the distinction between temporary and permanent lexical innovations - 'the former being changes lasting and functioning in a language for short periods of time, the latter being permanent additions to the semantic structure of the language. ${ }^{32}$ The lexicon of Czech, in common with that of all other languages, is constantly evolving, as a result of semantic broadening, narrowing or transfer, and the influence of lexical borrowing, as well as a range of extralinguistic factors. The emergent norms depend for their success at least partly on the backing of influential people and institutions, including politicians, journalists, historians, academics, lexicographers, school teachers, the security forces, the church and the judiciary.

\section{Lexical sources}

The primary collated and compendious sources of information on the meaning of words, especially in an historical context, are dictionaries, encyclopaedias (sometimes known in Czech as naučné slovníky [instructional dictionaries]) and corpora. These therefore form the basis of much of the discussion in this article. The relative frequency of temporal markers in the printed lexicon, and the extent to which understanding of their principal denotation(s) at a given time is taken as axiomatic or requires explanation or exemplification, serve as reasonably reliable indices of their status as historical signposts. It is, however, recognized that, despite their rarely challenged metalinguistic authority, dictionaries are far from infallible in terms of their choice of lemmas and definitions/ illustrations, and need to be supplemented by other sources of information. Monolingual dictionaries, in particular, are only as good as their selection of headwords and genus-differentiae definitions or practical examples (frequently in the form of contextual quotations), which are chosen to illustrate those words in a variety of surroundings. Zgusta has suggested that:

${ }^{31}$ Stern, Meaning and Change of Meaning, pp. 38-43.

${ }^{32}$ Kleparski and Rusinek, 'The Tradition of the Lexical Field and the Study of Lexical Semantic Change', p. 195. 
From these different applications, the lexicographer must derive the generalized description, or formulation, of the lexical meaning of which these applications (and eventually also the future ones) are actual manifestations. [...] This is the real difficulty of lexicography; the data consist exclusively of concrete, different applications of words (lexical units), but the goal of the lexicographer's work is their abstract value in the system. ${ }^{33}$

Dictionaries can at best only offer the potential 'core' meanings of words, and rarely allude to their pragmatic implicatures or extralinguistic associations. Other problems with lexicographical sources relate both to the constraints imposed on the interpretation of meaning by the nature of language itself, and by the unavoidable insufficiency of cultural and sociopolitical context in any given work. Dictionary entries inevitably tend to be self-referential and, in Lyons's words, 'usually combine paraphrase, in terms of partial intralingual synonymy, with analysis and description' ${ }^{34}$ Saeed has suggested that the three major 'challenges' posed to writers of dictionary definitions are the problem of circularity, the question of exactness (especially the distinction between linguistic knowledge and general knowledge), and the context dependency of meaning. ${ }^{35}$ There are also various difficulties outside the limitations of language and the dictionary itself. All lexicographical works are subject to ideological and practical constraints, which reflect the nature of the regime in power, the editorial policies of the publishing house, questions relating to finance and printing resources, the preconceptions of the editor(s) and compiler(s), and the existence of earlier editions and volumes of the same work. Electronic corpora and corpus-based dictionaries may provide a more accurate indication of frequency of usage and of meaning in context, but even they are only as comprehensive and as representative as their input sources, and may thus paradoxically sometimes present a narrower range of examples and a more partisan perspective than conventional lexicons. The Czech National Corpus (cited in note 4) is an outstanding source of lexical information, but unfortunately most of the texts currently available electronically are of a more formal nature and post-date 1989 (even though quotations and references within the texts may relate to earlier times). ${ }^{36}$

33 Ladislav Zgusta, Manual of Lexicography, Prague, The Hague and Paris, 1971, p. 26.

${ }^{34}$ John Lyons, Semantic Linguistics: An Introduction, Cambridge, 1996, p. 78.

35 John I. Saeed, Semantics, Oxford, 1997, pp. 6-7.

${ }^{36}$ The latest and largest available electronic corpus of the spoken language, ORAL 2008 , comprises one million words. The recent study of the language of state socialism by 
Where a radical transition in society intervenes to disrupt the lexicographical process, the situation facing the writers of dictionaries and encyclopaedias is even more complicated. Depending on the type of changes to the political system, compilers may be required or expected, or indeed feel inclined, to redefine or omit existing headwords, and to extend the number of entries to convey the new realities. This is perhaps best illustrated in Czech lexicography by Slovník jazyka českého [Dictionary of the Czech Language], published in four editions between 1937 and 1952; hereafter, SJČ (1937), (1941), (1946) and (1952). ${ }^{37}$ The change in ideological direction of the dictionary is most evident in the 1952 edition, which excludes any reference to the input of Pavel Váša, co-author of the three earlier editions. In his preface, Trávníček, an eminent linguist with strong Marxist-Leninist convictions, stresses that he has sought to reflect the changes in the lexicon relating to 'the victorious path to the new socialist order', and cites from 'the glorious articles about language' written by 'the great Stalin'.

Trávníček's contribution may not have directly influenced people's perception of reality, but his interpretation of social, political and economic change, reinforced by his repeated use of temporal phrases such as $v$ třídní společnosti (in a class society) and $v$ socialistic. společnosti (in a socialist society), symbolically underpinned the triumph of Communist Party dogma. His decision to include new vocabulary reflecting the spirit of the times, combined with selective omissions and reinterpretations of 'bourgeois' concepts, served as a powerful reminder of the break with the past. Expressions such as neúchylná cesta $k$ socialismu (the 'unswerving' path to socialism) and úchylkár (person who deviates [from Marxism]), introduced as an equivalent to the Russian word uklonist, further suggested the irreversibility of the transformation. Trávníček sanctioned a mixture of neologisms based on indigenous sources, including úchylkár and svazák (member of a union, most frequently the Czechoslovak Union of Youth), and others which more obviously bore the hallmark of Soviet-style socialism; for instance, the calques protilidový ('anti-people' [adjective];

František Čermák, Václav Cvrček, Věra Schmiedtová (eds), Slovník komunistické totality, Prague, 2010, based on texts from 1952, 1969 and 1977, which its editors say will be made available online, draws on around ten million words.

37 Pavel Váša and František Trávníček, Slovník jazyka českého, Prague, 1937, (2 Vols [A-K and L-Ž]), 1941 and 1946, and František Trávníček, Slovník jazyka českého, Prague, 1952. To save space, page numbers are not included here for dictionary citations. See also Tom Dickins, 'Reflections of Ideology in Slovník jazyka českého (1946-52)', in Robert Pynsent (ed.), The Phoney Peace: Central European Politics and Culture, 1945-1949, London, 2000, pp. 359-84. 
from Russian 'antinarodnyi') and stranickost vědy a umění (the Partymindedness of science and art; from Russian 'partiinost' [...]). Most striking of all were some of the direct borrowings from Russian, such as běloručka (literally 'a person with white hands [who does not work]', a bourgeois), bolševická zákalka (Bolshevik steeling) and rodná KSČ (the beloved Communist Party of Czechoslovakia). Equally noteworthy, but less eye-catching, was the selective redefinition of well-established cultural referents, including freudismus, interpreted in SJČ (1946) as 'instinctual psychology founded by Freud', and in SJČ (1952) as 'reactionary psychology founded by Freud'.

At their most extreme, the lexical and semantic innovations of the late 1940 os and early 1950 s are now so outdated as to sound parodic. Even the more up-to-date and authoritative sources from the socialist era, such as Slovník spisovného jazyka českého [Dictionary of the Standard Czech Language] (hereafter, SSJČ) and Slovník spisovné češtiny pro školu a veřejnost [Dictionary of Standard Czech for School and the Public] (hereafter, SSČŠV), contain entries which now seem anachronistic. ${ }^{38}$ This is not, however, to imply that all aspects of the vocabulary have changed equally radically. Many lexical fields, and the core meanings of their lexemes, have remained largely unaffected, as evidenced by the relatively minor changes required to make the first post-Communist edition of $S S \check{C} \check{S} V$ acceptable to its users. Where amendments were made in SSČŠV (1994), they were sometimes barely perceptible, as in the redefinition of národnost (nationality, defined in terms of ethnicity), where 'socialist' was substituted by 'democratic' in the phrase rovnoprávné postavení $n$-i $v$ socialistickém státè (the equal standing of nationalities in the socialist state), and the illustration of nezaměstnanost (unemployment), where 'industry' replaced 'capitalism' in the expression rüst $n$ - $i v$ kapitalismu (the growth of unemployment in capitalism). For all the shifts in usage of prevrat, only one of its exemplifications in SSČŠV (1978) was changed - kontrarevoluční převrat (counter-revolutionary takeover), strongly suggestive of a negative phenomenon, gave way to the more neutral-sounding revoluční prevrat (revolutionary takeover). ${ }^{39}$

${ }^{38}$ Bohuslav Havránek (principal ed.), Slovník spisovného jazyka českého, 4 vols, Prague, 1960 [A-M], 1964 [N-Q], 1966 and 1968 [R-U], and 1971 [V-Ž]) (reprinted without changes in 8 volumes in 1989, prior to the collapse of Communism), and Josef Filipec, František Daneš et al. (eds), Slovník spisovné češtiny pro školu a veřejnost, Prague, 1978 (revised in 1994).

${ }^{39}$ It is unclear to what extent editing costs may have dictated the number and scope of the changes made. 
The lexical signpost in context

In order to contextualize the importance of the notion of the lexical signpost in post-1918 Czech society, it is necessary to have at least an overview of the role played by mythopoeia in the creation and maintenance of the nation state. Whereas some peoples, such as the British, see their national development broadly in terms of linear historical continuity and take statehood more or less for granted, the Czechs are much more inclined to highlight key periods, events and individuals in their nation's past to define and justify their current existence as an autonomous state. The sharp reverses that have characterized the course of Czech history have promoted a tendency to accentuate the importance of 'national' selfrealization. Pride of place in Czech popular historiography arguably goes to the Great Moravian Empire (from 833 to 906) and the Golden Age of the Kingdom of Bohemia under Charles IV (1346-78). František Palacký and Tomáš Masaryk also stressed the role of Jan Hus, the Czech Reformation, Jan Ámos Komenský and Czech Protestantism until 1620. ${ }^{40}$ Amongst the principal turning points that have shaped national self-perceptions in more recent times have been the foundation of the First Republic (October 1918), the Munich Agreement (September 1938), the Prague Uprising (May 1945), the Communist takeover (February 1948), the Prague Spring and subsequent Warsaw Pact intervention (August 1968), the Velvet Revolution (November 1989) and the break-up of Czechoslovakia (January 1993).

The current legally recognized public (or 'state') holidays (státní svátky) and 'significant' days (významné dny) provide a clear indication of the importance of the major landmarks in Czech history, and the extent to which they promote a particular vision of society. ${ }^{41}$ The national holidays are: 1 January - Restoration Day of the Independent Czech State (Den obnovy samostatného českého státu), which doubles up as New Year's Day (Nový rok); 1 May — Labour Day or May Day (Svátek práce); 8 May - Liberation Day (Den osvobození); 5 July - Saints Cyril and Methodius Day (Den slovanských věrozvěstů Cyrila a Metoděje); 6 July - Jan Hus Day (literally 'The Day of the Burning-at-the-Stake of Master Jan Hus') (Den upálení mistra Jana Husa); 28 September - Czech Statehood Day (Den české státnosti) (the anniversary of the death of Saint

\footnotetext{
${ }^{40}$ See Rick Fawn and Jiří Hochman, Historical Dictionary of the Czech State, Lanham, MD, Toronto, ON and Plymouth, 2010, pp. 128-29, 154 and 182.

${ }^{41}$ These days are recognized by Czech law. See Vítejte na Pražském hradě, 'Zákon 245/2000 Sb. o státních svátcích, o ostatních svátcích, o významných dnech a o dnech pracovního klidu', 29 June $2000<$ http://old.hrad.cz/president/Havel/svatek/index.html> [accessed 30 April 2009].
} 
Wenceslas); 28 October - Czechoslovak State Independence Day (Den vzniku samostatného československého státu), and 17 November - Struggle for Freedom and Democracy Day (Den boje za svobodu a demokracii). The so-called significant days (which are normal working days) are 12 March - Day of the Entry of the Czech Republic to the North Atlantic Treaty Organization (Den př́stupu České republiky $k$ Severoatlantické smlouvě [NATO]), and 5 May - May Uprising of the Czech People (Květnové povstání českého lidu).

All of these celebratory days, with the exception of Labour Day (which was abandoned under Nazism but made 'compulsory' under Communism) and possibly the Christian festivals, contribute to Czech or Czechoslovak national mythopoeia, by denoting some kind of radical break with the past. (Compare public holidays in England and Wales, which are mainly either religious or seasonal, or occasionally note a royal celebration, such as a marriage or monarch's birthday. $)^{42}$ The resurrection of Czechoslovak State Independence Day was particularly poignant, in view of the Communists' reluctance to acknowledge the achievements of the First Republic. Similarly, the decision of the post-Communist authorities to switch from celebration of 9 May 1945, known previously as the Day of Czechoslovakia's Liberation by the Soviet Army (Den osvobození Československa sovětskou armádou), to celebration of 8 May 1945, when the Germans officially capitulated, is again indicative of a change in ideological direction.

Under Communist rule, there were fewer public holidays or work-free days (dny pracovního klidu) than there are today, with just six still in existence in 1989: 1 January, 1 May, 9 May, Easter Monday, and 25 and 26 December. Although Christian tradition was anathema to atheist dogma, and was at times heavily suppressed, Easter and Christmas were preserved as relics of what was officially deemed a bygone era. In a bizarre attempt to rewrite history, a so-called Nationalization Day (Den znárodnění), which related to the Nationalization Decrees (znárodňovací dekrety) signed by Beneš on 24 October 1945 and approved by the Provisional National Assembly on 28 October 1945, was chosen to replace Independent Czechoslovak State Day. Almost as oddly, the same day came to denote the proclamation of the Czechoslovak Federation (Prohlášení o československé federaci), which was endorsed by the Federal Assembly on 27 October 1968. In the mid seventies, perhaps in recognition of the absurdity of the existing

${ }^{42}$ In Scotland, St Andrew's Day is now an alternative voluntary public holiday, and in Northern Ireland, both St Patrick's Day and the Battle of the Boyne (Orangemen's Day) are statutory holidays. The nearest to a 'political' celebration in most of Britain might be 5 November. 
compromise (which paradoxically drew attention to the Communists' policy of promoting the absence of memory of 'inconvenient' events) and perhaps on economic grounds, 28 October was reduced to the status of a significant day. ${ }^{43}$ Other significant days were 25 February - Victory Day of the Working People (Den vitězství pracujícího lidu), which marked the Communist seizure of power; 29 August - Slovak National Uprising (Slovenské národní povstání), and 7 November - (Russia's) Great October Socialist Revolution (Velká ř́ijnová socialistická revoluce), which was so well established in the Czech lexicon that it was often just referred to in writing by the initialism $V \check{R} S R$. Also identified as historically important were 5 July and 6 July, as above, which were officially known before 1989 as noteworthy days (památné dny).

The names of at least two-thirds of the months have contributed significantly to the mapping of Czech(oslovak) history - January, in the phrase muži ledna (the men of January) (alluding perhaps to muži řijna, below), which denotes high-ranking Party members closely identified with Dubček's reforms, who came to prominence at the January 1968 plenum of the Central Committee of the Communist Party; February, in phrases such as Vitězný únor (Victorious February), which identifies the Communist takeover in 1948; March, in breznové povstání (the March Uprising [in Vienna and Hungary]), likewise known as breznová revoluce (the March Revolution), in 1848; May, in květnové povstání (May uprising) in 1945; June, in Pražské červnové povstání (Prague June Uprising) in 1848; August, in expressions such as srpnové události ('the August events'; the Warsaw Pact intervention) in 1968; October, in ř́inový prevrat and muži ř́ijna (the men of October), referring to the leaders of the National Committee (Antonín Švehla, Jiří Stř́ibrný, Alois Rašín, František Soukup and Vavro Šrobár) who signed the proclamation of independence in 1918, and November, in listopadová revoluce (the November Revolution), listopadový prevrat and so forth, in 1989. Other descriptors which serve a similar temporal function include husitský (Hussite), mnichovský (Munich), přelomový (historically groundbreaking) and převratový. Some scholars have also (perhaps flippantly or opportunistically) highlighted the phenomenon of the 'fateful eights' - the tendency of events of national importance to

43 The second volume of Bohumil Kvasil et al., Malá československá encyklopedie [The Small Czechoslovak Encyclopedia] (6 vols), Prague, 1984 [A-Č], 1985 [D-Ch], 1986 [I-L], 1986 [M-Pol], 1987 [Pom-S] and 1987 [ک̌-Ž], gives a more enlightening entry than some publications: Den znárodnění, vyhlášení samostatnosti ČSR, vznik čs. federace (Nationalization Day, declaration of the independence of the Czechoslovak Republic, the establishment of the Czechoslovak Federation). 
occur in years ending in -8 but, while the coincidence has a quirky appeal, it does not appear to have acted as a stimulus for major social or political transformation. ${ }^{44}$

\section{The First Republic}

The raison d'être of the First Republic was Czech and Slovak selfdetermination. ${ }^{45}$ Amongst the entries in SJČ (1937), which sought to reinforce the message that the Habsburg Dynasty and the Dual Monarchy of Austria-Hungary had been consigned to history, were demokracie (democracy, 'government of the people, government set-up against the monarchy etc. [...]'), nadpráví (arrogation, 'more than that which appertains according to the law, [unjust] claims for it: arrogation by the Germans in old Austria [...]'), čs. zahraniční odboj (za světové války) (Czechoslovak foreign resistance [during the Great War]) and washingtonská deklarace (Washington Declaration, 'proclamation of Czechoslovak independence on $18 / 10 / 1918$ '). Each usage served to consolidate the others in the same lexical field, and helped symbolically to cement the transformation from Habsburg rule to an autonomous nation state.

Many of the fixed expressions denoting a change in the status of the regime are universally recognized historical descriptors and, as such, require no further commentary; for instance, vznik Československa (the emergence of Czechoslovakia), založení československého státu (the foundation of the Czechoslovak state) and zřizení ČSR (the establishment of the ČSR [Czechoslovak Republic]). Of greater interest in the context

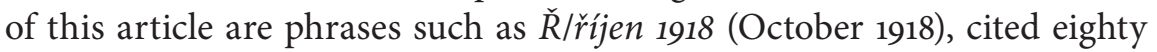
times in SYN 2010, which depends for its meaning on an individual's encyclopaedic knowledge of the Czech- and Slovak-speaking lands, and the composite name transfers, (státní) převrat and (československý/zahaniční) odboj (the [Czechoslovak/foreign] resistance), which derive their meaning largely from context. The term odboj fulfils all the criteria of an historical signpost, and remains one of the most important referents in Czech historiography. Not only was it applied to the rebellion of the Czech and Slovak legionaries against Austria-Hungary (1914-18) (and occasionally also to the subsequent revolt against the Bolshevik authorities during the

\footnotetext{
${ }^{44}$ See, for example, Petr Čornej, Jiří Pokorný, Milena Bartlová et al., Osudové osmičky: přelomové roky v českých dějinách, Prague 1999, and František Emmert, Osudové osmičky $v$ našich dějinách, Brno, 2008, which was based on the Czech Television programme Osudové osmičky: Kalendárium událostí našich dějin.

45 The question of the extent to which the Slovaks determined their own destiny is beyond the scope of this study.
} 
anabasis of the so-called 'Russian legionaries'), but it has also been used to refer to anti-Nazi resistance during the Second World War, and to antiCommunist opposition from 1948 to 1989. A distinction is sometimes made between první odboj (the first resistance [during the Great War]), druhýl protinacistický/protifašistický/protihitlerovský odboj (the second/anti-Nazi/ anti-fascist/anti-Hitler resistance) and třetí/protikomunistický odboj (the third/anti-Communist resistance). In SYN 2010, there are eight citations for P/prvni odboj and its derivatives (of which four appear in conjuction with druhý), thirteen for druhý odboj-, forty-one for protinacistický odboj-, twentyfive for protifašistický odboj-, four for protihitlerovský odboj-, forty-seven for T/třetí odboj- (of which two appear in conjunction with druhý) and thirty for protikomunistický odboj-. Similarly worthy of note is the most obvious of all lexical indicators, meznik (turning point), cited 580 times in SYN 2010, which is illustrated in SJČ (1937) by the phrases 'a turning point in the life of an individual; 28 October 1918 is a turning point in Czechoslovak history', but in subsequent editions only by the former of the two phrases.

The major difficulty faced by both the German wartime authorities and the Communists was that, try as they might to change the course of history and to alter the designations of words, they could not altogether eradicate their established associations and connotations. For most Czechs, 1918 has (quite understandably) always been recognized as the principal turningpoint in the development of the nation state, and while its importance could be downplayed in officially sanctioned publications, it could not be removed from existing repositories of knowledge or the nation's collective memory. Even staunch Communists could not deny the role of 1918 in national self-realization, or claim with any legitimacy that February 1948 was of greater significance in the history of the Czech and Slovak peoples. Communist historians such as Král, in his study of historical landmarks, did not altogether ignore 1918, but rather challenged the 'bourgeois' interpretation of the role the Triple Entente and of the Czech and Slovak resistance in the overthrow of Austria-Hungary. Král goes so far as to argue that

The historically inaccurate linking of the foundation of the Czechoslovak state with the counter-revolutionary intervention in Siberia was intended [...] to strengthen anti-Communist and openly pro-fascist tendencies in Czechoslovakia's internal politics in the 1930 s. $^{46}$

${ }^{46}$ Václav Král, Historické mezníky ve vývoji Československa, Prague, 1978, p. 33. 
The suggestion that the Czechoslovak authorities were deliberately promoting pro-fascist sentiment complies with the simplistic and doctrinaire Communist view of 'bourgeois' democracy as a broad coalition of anti-Marxist-Leninist forces and interests.

Central to the 'myth' of the First Republic was the role of Masaryk, president of Czechoslovakia from 1918 to 1935, whose combination of enlightened patriotism and paternalism earned him the respect and affection of a great many Czechs and Slovaks. The unofficial titles attributed to him - tatíček (daddy) and TGM - suggest a fondness rarely accorded to a long-serving head of state, and the formal appellation president Osvoboditel (liberator president) affirmed his position as the principal founding father of the Republic. His iconic status was reinforced in December 1935 by legal recognition of his contribution to the liberation of the Czechoslovak people and the building of the Czechoslovak state (jeho osvoboditelské a budovatelské dílo). ${ }^{47}$ Masaryk's legacy to the Czech lexicon is demonstrated not only by his own contributions, such as barikádní boj (fighting on the barricades) and jinorodec (foreigner), and by the phrases which he 'popularized', such as ujasnit si své názory (to clarify one's thoughts), but also in the various derivatives of his name, including the adjective masarykovský (Masarykian), masarykovec (follower of Masaryk), masarykismus (Masaryk's philosophy) and masarykiáda (a type of educational olympiad). In the immediate post-war period, Masaryk's successor, Beneš, took on the mantle of 'master builder' or '(chief) architect' (budovatel), but by then the term had begun to acquire more radical political associations. ${ }^{48}$ Nowadays, Benešs name is perhaps more generally associated with his set of controversial decrees (Benešovy dekrety or, more formally, dekrety presidenta republiky [Decrees of the President of the Republic]), which are often taken as the basis for the expulsion of Germans and Hungarians from post-war Czechoslovakia. It is not insignificant, in the context of this article, that the exhaustive post1948 campaign to discredit Masaryk and Beneš ${ }^{49}$ was accompanied by the reappropriation of both osvoboditel and budovatel and their derivatives

47 See Portál veřejné správy České správy, 'Zákon č. 232/1935 Sb., o státní poctě prvnímu presidentu Československé republiky', 21 December 1935 <http://portal. gov.cz/wps/portal/_s.155/701/.cmd/ad/.c/313/.ce/10821/.p/8411/_s.155/701?PC_8411_ number2=69\&PC_8411_l=232/1935\&PC_8411_ps=25> [accessed 3 May 2010].

${ }^{48}$ See, for example, Bohuslav Šmeral, President Budovatel: život a dílo Edvarda Beneše, Brno, 1946, and Josef Kuchynka et al., President Budovatel: Příručka pro oslavy 28. května, narozenin Dr. Ed. Beneše, Třebechovice pod Orebem, 1947.

${ }^{49}$ See, for example, Zdeněk Fierlinger, Zrada československé buržoasie a jejích spojencü, Prague, 1951, and František Nečásek, Jan Pachta, Eva Raisová (eds), Dokumenty o protilidové a protinárodní politice T. G. Masaryka, Prague, 1953. 
- the former was linked with the Red Army, in phrases such as sovertští osvoboditele (Soviet liberators); the latter with socialist construction, as in budovatelský román (constructionist novel) and budovatelské nadšení (constructionist enthusiasm).

\section{The German occupation and its aftermath}

While memories of the First Republic may have given hope to some Czechs and Slovaks during the war, Czechoslovakia was effectively written out of lexicographical works and history books under the Protectorate of Bohemia and Moravia (1939-45). Masaryk became officially virtually a non-person and Beneš, who presided over the Czechoslovak Governmentin-Exile in England, was treated as a persona non grata. All lemmas which alluded to the nation state, including rusko-československý (RussianCzechoslovak) and Malá dohoda (Little Entente) in SJČ (1937), were omitted from SJČ (1941), and references to Masaryk, except as a source, likewise disappeared. The decision not to reinstate entries such as washingtonská deklarace and masarykovský duch (the spirit of Masaryk) in the 1946 edition of the dictionary suggests the extent to which the direction of the political signposts had shifted towards Moscow. Unlike Masaryk, Lenin is referred to explicitly in all four editions of SJČ, under the exoticism Leninie, defined as 'Lenin's country, Soviet Russia' (by the poet Josef Hora), with leninismus (Leninism), defined as 'a direction in Russian Bolshevism adhering strictly to Lenin's teachings' in the first three editions and as 'Lenin's teachings, Lenin's contribution to Marxism, Lenin's development [rozvití] of Marxism' in the fourth (1952) edition. ${ }^{50}$

In the immediate post-war period, the 'progressive' political consensus, coupled with restrictions on printing materials, made it difficult to laud the achievements of the First Republic. However, at least one lexicographer, Karel Tauš, appears to have been keen to rehabilitate Masaryk's reputation. In the second edition (only) of his unusual, but not unworthy publication, Slovník cizích slov, zkratek, novinářských šifer, pseudonymů a časopisů pro čtenáre novin [A Dictionary of Loan-words, Abbreviations, Journalists' Ciphers, Pseudonyms and Periodicals for Newspaper-readers], he included the entry TGM, with the definition 'a glorious brandname [značka], known to the whole nation, the initials of the name of the President Liberator Tomáš Garrigue Masaryk., ${ }^{51}$

${ }^{50}$ The Molotov-Ribbentrop Pact was still intact at the time Váša and Trávníček wrote the second edition, so references to Soviet Russia were not subject to the same degree of German censorship as they were subsequently.

${ }^{51}$ Karel Tauš, Slovník cizích slov, zkratek, novinářských šifer, pseudonymů a časopisů pro čtenář novin, Blansko, 1946, and Slovník cizích slov [...], Blansko, 1947 (second amended 
Perhaps the most striking feature of Taušs work is the extent to which the war serves as a temporal frame. Slovník cizich slov [...] (1946 and 1947) clearly demarcates four periods in terms of the war: the pre-war years, the Protectorate, the fight for freedom, and the post-war era. The first phase is represented by descriptors such as pred (poslednildruhou světovou) válkou (before the [last/second world] war), až do začátku války (before the start of the war), pred vypuknutím války (before the outbreak of war) and pred okupací (before the occupation). The second phase is illustrated by expressions such as za (druhé světové) války (during the [second world] war), za (německé) okupace (ČSR) (during the [German] occupation [of the ČSR]), pod tlakem nèmecké okupace (under the pressure of the German occupation), v Hitlerově t. $z v$. Třetí ríši (in Hitler's so-called Third Reich), za éry nacistické (during the Nazi era) and až do vitézného května 1945 (up till victorious May 1945). Designations of the third phase include $v$ revolučnim období 1945 (in the revolutionary period of 1945) and osvobozovací boje $v$ květnu 1945 (liberation struggles in May 1945). The fourth phase is exemplified by phrases such as po květnovém prevratu v roce 1945 (after the May takeover in 1945), od znovunabytí stát. samostatnosti (since the reclamation of state independence), po (druhé světové) válce ( $v$ roce 1945) (after the [second world] war [in 1945]), po velké poslední válce proti fašismu (after the last great war against fascism) and po vyhnání násilných nèmeckých okupantů (after the expulsion of the violent German occupiers). Despite Taušs apparent affection for Masaryk, the dictionary makes it abundantly clear that post-war Czechoslovakia represented a clean break from the past, and was not in any sense a continuation of prewar Czechoslovakia.

The repeated references to the Germans as an occupying power served to reinforce the Czechs' increasingly exclusive claims on the traditional territories of the Bohemian Crown. The noun odboj and its derivatives, such as odbojár (resistance fighter), collocate most frequently in SYN 2010 with terms relating to the Second World War, including Obrana (národa) (Defence [of the Nation]), UVOD (Ústřední vedení odboje domácího) (Central Command of the Home Resistance), okupant (occupier) and nacista (Nazi). After the war, virtually all native German speakers, with a few notable exceptions, were condemned as okupanti and kolaboranti (collaborationists), and were thus deemed legitimate

and expanded edition). For a fascinating study of the first edition, see David Short, 'A New Use for Bohemian Crystal: Karel Taušs Dictionary of Loan-Words', Central Europe, 5, 2007, 2, pp. 147-58. 
subjects for forcible and frequently violent eviction..$^{2}$ The 'TriumphOver-Enemy-Forces' Narrative Template, as Wertsch calls it (in the context of the Russian Civil War), has its own lexicon in Czech, which needs little explanation to educated native speakers. ${ }^{53}$ Amongst the many expressions which contribute to this particularly emotive lexical field are odsun (evacuation), vysídlení (compulsory resettlement), vyhnání (expulsion), deportace (deportation) and transfer (nèmeckého obyvatelstva) (transfer [of the German population]). The noun okupace exemplifies all six of the characteristics of a lexical signpost: it is central to Czech historiography; it became subject to permutation in August 1968; it had quite different connotations for a large number of bilingual Czech speakers (principally ethnic Germans and Hungarians); it had an impact on other analogous and semantically related lexical items, such as its statistically less common synonym obsazení; it frequently occurred in set expressions, including Za/za okupace, cited 124 times in SYN 2010, and O/ okupace Československa, cited 103 times (compared with seven citations for obsazení Československa), and it has spawned derivatives, including the adjective okupační (occupying). As a collocate of okupace and obsazení in SYN 2010, Československo (Czechoslovakia) has t-scores of 9.897 and 2.638, respectively, in the range o to 1 .

Other terms used to depict the Protectorate in the post-war years, which were later applied by its opponents to state socialism, included (nacistická) totalita ([Nazi] totalitarianism), doba nesvobody (period of lack of freedom), hruizovláda (reign of terror) and zvi̊le (arbitrary rule, despotism). SSJČ (1966-68) and SSČŠV (1978) offer the following definitions of totalita: '(as a rule in a fascist regime) violently established unity [jednota]: totalitarianism established from above', and 'unity (of a fascist state) established and maintained by violence', respectively. By contrast, odpolitizování (depoliticization) was popularized by the National Socialists to mean a 'return' to pre-twentieth-century German domination, and assimilation within the Reich, ${ }^{54}$ but it has also been used in relation to the stagnation of Czechoslovak society resulting from normalization after 1968, and to the 'deidelologization' (deideologizace) of the media and other institutions after 1989. It is this diachronic dimension to the lexical signpost, based on the reapplication of a well known term to a different

52 The first Czech dictionary definition of kolaborant is from SJČ (1952): 'co-operator, as a rule with the enemy, during the Second World War with Nazism, lackey'.

53 See Wertsch, Voices of Collective Remembering, pp. 99-101.

54 See Jiř́i Doležal, Česká kultura za Protektorátu. Školství, písemnictví, kinematografie, Prague, 1996, pp. 12-13. 
referent, which distinguishes it from words in static semantic fields, such as colours and parts of the body.

\section{Communist Czechoslovakia}

Whereas the National Socialists denied the legitimacy of the existence of the Czechoslovak state, the Communists implicitly embraced the idea of the nation state but rejected the symbolism of the triumph of 'bourgeois' democracy. The German occupation and its underlying economic causes provided the Communists with the 'evidence' and opportunity that they needed to challenge the legitimacy of the pre-war status quo. As the political faction least tainted by association with bourgeois ideology, they were ideally placed to tap into the widespread resentment over the allies' role in the Munich Agreement (Mnichovská dohoda), which had become a synonym for national humiliation. In SJČ (1952), Mnichov (Munich) is defined as 'the symbol of our national and state catastrophe in September 1938, caused by the bourgeoisie here and abroad, in the West'. The same dictionary defines mnichovák ('Münchner') as 'a person agreeing with the bourgeois politics of the First Republic, which led to Munich, and to the demise of the ČSR'. The Communists also employed the device of the temporal frame to make a more explicit connection in people's minds between liberal democracy and the German occupation, as exemplified by phrases such as predmnichovská buržoazní republika/demokracie (preMunich bourgeois republic/democracy). The adjective P/předmnichovský is cited forty times in SYN 2010, and nowadays collocates most frequently with hranice (borders).

The majority of Czechoslovak citizens, excluding most ethnic Germans and Hungarians, accepted the Communist interpretation of the Munich Agreement as an act of treachery. Amongst the pejorative epithets applied to the Agreement were Mnichovský diktát (Munich Diktat), Mnichovská zrada (Munich Betrayal), zrada spojencu (betrayal by the allies) and zrada Západu (betrayal by the West), and the well known slogan $O$ nás bez nás (About us, without us). It is telling that, whilst almost all of the other Communist rhetoric has now fallen out of favour, the phrases Mnichovsky diktát (Munich Diktat) and Mnichovská zrada (Munich Betrayal) are still widely used today. Such was the negative psychological impact of the Munich Agreement on most Czechs that historians still speak of mnichovský komplex (the Munich complex). ${ }^{55}$

55 See, for example, Jan Tesař, Mnichovský komplex. Jeho př́ičiny a důsledky, Prague, 2000. 
One of the defining features of the first few years of the Communist regime was the way it exploited anti-foreign sentiment for its own ends. The Communists employed the 'Triumph-Over-Enemy-Forces' template, culminating in the show trials of the early 1950s, as a way of reinforcing Stalinist orthodoxy. Amongst the unpatriotic elements targeted were a range of 'informers', 'spies', 'opportunists', 'saboteurs' and other 'antiCommunist' individuals and groups, all with links to external powers. (Paradoxically, the Party's modus operandi was itself inspired and directed by a foreign power - the Soviet Union.) In the trial of Rudolf Slánský et al., the alleged enemies of the state working for (or with connections to) outside bodies or so-called national separatist movements included agenti imperialistických/západních rozvědek (agents of imperialist/Western espionage groups), američtílangličtíljugoslavští vyzvědači (American/ British/Yugoslav intelligence officers), anglo-američtí imperialisté (Anglo-American imperialists), londynéri/přislušníci londýnské emigrace ('Londoners'/members of the London émigré circle), sionistélsionističtí agenti (Zionists/Zionist agents), slovenštílžidovští buržoasní nacionalisté (Slovak/Jewish bourgeois nationalists), titovci (Titoists) and židovští kšeftaři a fabrikanti (Jewish money-makers and factory owners). ${ }^{56}$ The decision to attack the Jews was particularly grotesque in view of the untold suffering and virtual decimation of the Czech and Slovak Jewry during the war. Not only was the language used ominously reminiscent of the antisemitism of the Nazis, but the Communists cynically exploited a long tradition of linking Jewishness with the forces of outside opposition, especially Germanization.

The tragedy of the show trials and the frightening reality of many people's lives stood in stark contrast to the official optimism of the early Communist period. The yearnings for a new beginning are manifest in the public discourse of the time, as evidenced, for instance, by a quote from the journal Milotický hospodár (which ceased publication in 1948), cited in Přiruční slovník jazyka českého [Reference Dictionary of the Czech Language] (1955-57) to illustrate zitřek (tomorrow): 'We must build a base for a better tomorrow, a more joyous future for all the working people [pracujicílid] of the Republic, on the path to socialism. ${ }^{57}$ By the early 1950 s there were literally dozens of allusions to the dawn of a new age, including světlé zitřky (bright tomorrows), kupředu $k$ zár̆ným zitřkiom (forward to

${ }^{56}$ All the examples cited here are taken from Proces s vedením protistátního centra $v$ čele s Rudolfem Slánským, Prague, 1953.

57 Bohuslav Havránek, Vladimír Šmilauer, Alois Získal (eds), Př́ruční slovník jazyka českého (8 vols), vol. 7, Prague, 1935-57. 
shining tomorrows), víra $v$ lepší zitřek (belief in a better tomorrow), lépe a radostněji (better and more joyously), postaru se žít nedá (we can't live in the old way) and zpátky ni krok (not a step backwards), to name but a few. Characteristic of the slogans was the unchallengeable assumption of the inevitability of social progress and the irreversibility of the political process. Each of the elements in this propaganda campaign was intended to reinforce the others within the same conceptual domain, thereby consolidating the untenability of alternative world views. In practice, however, many people regarded the slogans with increasing cynicism, and the relatively rapid decline in their use suggests that even the Communists implicitly recognized the discord between their rhetoric and reality.

While the Communist Party periodically acknowledged selective shortcomings in the system which it controlled, the unassailable triumph of state socialism was never seriously questioned. The righting of the past and the rewriting of history became an ideological ritual designed merely to affirm the leading role of the Party. (Even in 1968, most of the Communist reformers who spoke of 'socialism with a human face' resisted calls for genuine pluralism.) Amongst the officially approved phrases denoting the Communists' accession to power were prevrat, Unor 1948 (February 1948) (generally written with a capital 'Ú'), historický Únor (historical February), únorové události (the events of February) ${ }^{58}$ and Vitězný únor (usually with a capital ' $\mathrm{V}$ '). As elsewhere, the name of the temporal indicator is frequently qualified by the prefixes do or pred (pre-) and po (post-). There are fifty-eight citations of predúnorový (pre-February) and 297 citations of poúnorový (post-February) in SYN 2010, relating exclusively to February 1948. Phrases such as poúnorový exil (post-February exile) and polistopadový vývoj (post-November development) would require little further contextualization to be understood by educated speakers of Czech, whereas a translator would probably need to add the year in question, even if writing for a well informed readership.

In the collocation V/vitězný únor, cited fifty-five times in SYN 2010, the existing epithet vitězný was also reappropriated for new purposes. The use of vitézný drew on the prevailing sense of triumph over the defeat of Hitler (in Taušs phrase vitězný květen [victorious May] and other common expressions, such as vitězství nad fašismem [the victory over fascism]), thereby implicitly linking the success of Communism with the overthrow of Nazism. The entry for únorové události 1948 in Př́ruční slovník

58 The phrase únorové události (1934v Rakousku) (the events of February [in Austria 1934]) was also used of the uprising of Viennese workers against the Dollfuss government. 
naučný [Reference Encyclopedic Dictionary] (1967) begins (somewhat controversially) as follows: 'the victory of the Czechoslovak working people over bourgeois reactionary ideology, which sought to stop the development of the Czechoslovak Republic in February 1948 by means of a counterrevolutionary putsch [...]' (my italics - TD). ${ }^{59}$ The same theme is alluded to in SSJČ (1971) in the phrase únoroví pučisté (February putschists), cited from the daily newspaper Mladá fronta. Not only did the Communists' use of subjective platitudes, such 'the victory of the working people', simplify reality, but their partisan interpretations of history, as expressed in phrases such as 'a counter-revolutionary putsch', were deliberately misleading. The repetition of shibboleths and sophistries created the illusion of a shared ideological conviction, but the veracity of the Party line was, of course, frequently questioned in private discourse. Indeed, throughout the Soviet bloc, people drew a clear distinction between private and official 'truths'. Yurchak has described the citizen, in the context of late Soviet society, as a dissimulator who acted differently in the 'official public' and 'hidden intimate' spheres. ${ }^{60}$ In Saussurean terms, there was a disjunction between the official 'sign' and the private 'sign'.

The Communist authorities drew an axiological contrast between the forces of progress or 'good' (represented by the Party and its ideology) and reaction or 'bad' (all opposition to the Party and Marxism-Leninism). The term puč appears to have had uniformly negative associations, as shown by the examples used to illustrate it in SSJČ: 'counter-revolutionary, anti-state, anti-people [protilidový]; military putsch; suppression of a fascist putsch', whereas revoluce (revolution), more frequently than not, had positive connotations. (The tendency to avoid the collocation únorová revoluce [February Revolution], in a Czech context, was presumably attributable to the possible confusion with the February Revolutions in Paris in 1848 and in tsarist Russia in 1917, generally known in Communist times as 'Únorová revoluce', often in inverted commas, and Únorová buržoazně demokratická revoluce [the February Bourgeois Democratic Revolution], respectively.)

It is no accident that some opponents of the former Communist regime have adopted the word $p u \check{c}$, in relation to the events of 1948, as a way of undermining the legitimacy of the establishment of the Communist

59 Vladimír Procházka (principal ed.), Př́ruční slovník naučný, 4 vols (vol. 4), Prague, $1962[\mathrm{~A}-\mathrm{F}], 1963[\mathrm{G}-\mathrm{L}], 1966[\mathrm{M}-\check{\mathrm{R}}]$ and $1967[\check{S}-\check{Z}])$.

${ }^{60}$ Alexei Yurchak, Everything was Forever, Until it was No More: The Last Soviet Generation, Princeton, NJ, 2006, p. 17, cited in Paulina Bren, The Greengrocer and His TV: The Culture of Communism after the 1968 Prague Spring, Ithaca, NY and London, pp. $102-03$. 
government, but the term simply does not bear this interpretation. There is no doubt that the Communists manipulated the post-war situation and employed tactics incompatible with liberal democracy, but it is equally beyond dispute that, in the Czech-speaking lands and Czechoslovakia as a whole (if not in Slovakia), they enjoyed more widespread popular support than any of their permitted rivals, following the banning of the Agrarian Party. Prior to 1948, the Communists held two-thirds of the seats in the National Front, ran several key ministries, including the Ministry of the Interior and the Ministry of Information, and effectively controlled the Revolutionary Trade Union Movement $(R O H)$. Král makes a valid point when he asserts that 'February was the victory of the massed millions, and it is therefore nonsense to call this undertaking by the people a "putsch"' ${ }^{61}$

Like puč, the term prevrat is also an inaccurate designation of the Communist takeover (as, indeed, it was for the events of November 1989), since it implies a degree of physical force which was largely absent. SSJC defines prevrat as follows: 'a change in the leadership of the state or in the political system of the state carried out suddenly and as a rule violently.' An historically more precise description of February 1948 might be uchopenil převzetí moci komunisty/Komunistickou stranou (seizure/takeover of power by the Communists/Communist Party), but neither phrase has the emotional appeal or rhetorical impact of, say, Vitězný únor or komunistický puč (Communist putsch). The term 'coup', which is frequently preferred in English, would likewise seem to be an inadequately imprecise descriptor, based on its definition in the Oxford Dictionary of English as 'a sudden, violent and illegal seizure of power from a government'.62

The 1948 takeover was presented by the Communists both as a continuation of the post-war socialist era, as suggested by the retention of existing designations for the country, such as lidover demokratická Československá republika (Czechoslovak people's democratic Republic) and lidový stát (people's state), and as a complete break from the past, as illustrated by the decision not to adopt the title 'Fourth Republic' (following on from the Second Republic [1938-39], and the Third Republic [1945-48]). Whereas it was politically expedient for the Communists to take as much credit as possible for the shaping of the future socialist society, they were keen to avoid any appellations, such as 'Fourth Republic', which might implicitly acknowledge the pre-1945 national legacy. Indeed, they not infrequently ignored the First Republic altogether, and increasingly

${ }^{61}$ Král, Historické mezníky ve vývoji Československa, p. 172.

${ }^{62}$ Catherine Soanes and Angus Stevenson, Oxford Dictionary of English, 2nd edn, Oxford, 2006. 
treated the entire period till the end of the war as a discrete entity, which was deemed to be of relatively little relevance in the context of socialist reality. This point is implicit in the exemplification of mezník in SSČŠV (1978): 'the socialist revolution, a turning-point in the history of mankind'. It is also borne out by Mala československá encyklopedie, which employs the title obdobi monopolistického kapitalismu (the period of monopolistic capitalism) to describe the years 1900 to 1945 . At the very best, this descriptor is too loose to be informative; at worst, it is a cynical attempt to reiterate the message that the different manifestations of 'bourgeois' politics (including National Socialism), and its means of production, were essentially indistinguishable.

The Communists' efforts to impose a new official interpretation of reality frequently ran counter to existing constructs of meaning. For instance, SJČ (1952) defines individualismus (individualism), in its 'socialist' sense, as 'an attempt by the individual to assert his/her skills in work for the [good of the] whole' - a definition which must have appeared almost the antithesis of its objective reference to many Czechs. Likewise, the redesignation in 1960 of Czechoslovakia as a socialist democracy (socialistická demokracie), with the new official title of Československá socialistická republika (ČSSR) (the Czechoslovak Socialist Republic), must have seemed arbitrary, as it was not accompanied by any significant changes in the structure of society. In private discourse, the term 'socialist democracy' was treated with growing scepticism and, as discussed below, was often substituted by the (academically not altogether accurate) Western alternative 'Communism', which has now become a virtual synonym for it. An even more illuminating illustration of the effect of Marxism-Leninist dogma on the interpretation of meaning is to be found in the definition of lidská práva (human rights) in Malý encyklopedický slovník [The Small Encyclopaedic Dictionary] (1972), with its emphasis on 'the economic and social rights of workers, enshrined in the constitutions of socialist countries. ${ }^{63}$ Again, in private, many Czechs questioned this partial and partisan interpretation, and conceived human rights more broadly. As is well known, the question of the observance of Article 7 of the Final Act of the 1975 Conference on Security and Cooperation in Europe (Respect for human rights and fundamental freedoms) subsequently formed part of the basis for the drafting of Charter 77.

For opponents of hard-line Communism, Pražské járo (the Prague Spring) - a term promoted in its wider ideological sense by the Western

${ }^{63}$ Unnamed editorial team, Malý encyklopedický slovník, Prague, 1972. 
media - represented the last serious attempt to reform the socialist system. The Warsaw Pact intervention in August 1968 was officially justified by the Moscow Protocol (Moskevský protokol) which rendered 'the so-called Fourteenth Congress of the KSČ [Czechoslovak Communist Party]' ( $t z v$. XIV. sjezd KSČ) illegitimate, and pledged a new congress to resolve 'questions of the normalization of the situation in the country' (otázky normalizace situace $v$ zemi). ${ }^{64}$ (It might be noted that $t z v$. has been used not just by Communists, but also by their opponents, to qualify virtually anything which meets with their disapproval, or which might be subject to an alternative interpretation.) The negative associations of the trope normalizace were so strong that in 1969 President Husák tried, with limited success, to replace it with konsolidace (consolidation). ${ }^{65}$ To this day, normalizace, in its metaphorical political sense, is synonymous in the minds of many Czechs with imposed conformity and lack of freedom of expression. In Sternian terms, the subjective apprehension has effectively replaced the objective reference as the principal denotation or, put more simply, non-basic denotative meaning has supplanted the noun's 'core' meaning. The Moscow Protocol concluded with a pledge that Czechoslovakia and the USSR would do their utmost to promote 'a deepening of the traditional historical friendship of the peoples of both countries, and their fraternal friendship for evermore' (na věčné časy) - a promise which must have sounded like an undisguised threat to many Czechs. ${ }^{66}$

Despite public expressions of gratitude to their allies for fraternal assistance (bratrská pomoc), and repeated references to the years 1968-69 as krizové obdobi (a period of crisis), the pro-Moscow Communists never enjoyed widespread support after August 1968. Husák's normalizační režim (normalization regime) was dubbed, amongst other things, vláda konformismu (the conformism government) and vláda 'šedé zóny' (the 'grey zone' government) - phrases denoting a form of governance which aimed to appease the largely apolitical and consumer-orientated silent majority. Bren, with reference to Šiklová, argues that the concept of the 'grey zone' has been perceived simplistically as a kind of no-man's land between two neatly dug trenches, occupied by the Party elite, on the one side, and opponents of the regime, on the other. ${ }^{67}$ This diametric opposition was

\footnotetext{
${ }^{64}$ Protokol o jednání delegace ČSSR a SSSR (tzv. Moskevský protokol), 27 August 1968 $<$ http://www.totalita.cz/texty/prot_mosk_1968.php> [accessed 15 June 2010].

${ }^{65}$ See Fawn and Hochman, Historical Dictionary of the Czech State, p. 173.

${ }^{66}$ Protokol o jednání delegace ČSSR a SSSR.

${ }^{67}$ Bren, The Greengrocer and His TV, p. 8; Jiřina Šiklová, 'The 'Gray Zone' and the
} 
reinforced in popular parlance by a range of terms for the representatives of the two camps: aparátčíci (apparatchiks), nomenklaturníci (members of the nomenklatura), totálníci (advocates of totalitarianism) and dojiči socialismu (milkers of socialism), versus opozičníci (members of the opposition), chartisté (members of Charter 77) and muklové (political prisoners). In reality, the grey zone reached into both trenches, and many people, including the so-called osmašedesátníci ('the sixty-eighters' reform Communists who failed to renounce their beliefs after the Warsaw Pact intervention), did not sit comfortably anywhere.

Overt references to the military intervention in the public domain were kept to a minimum, and the night of 20-21 August 1968 was largely assigned to the non-memory of history. ${ }^{68}$ However, where its mention was unavoidable, it was generally referred to as vstup vojsk Varšavské smlouvy na území ČSSR (the entry of the troops of the Warsaw Pact onto the territory of the ČSSR), and more colloquially vstup spojeneckých vojsk (the entry of the allied troops), or in certain circles by the codename Operace Dunaj (Operation Danube). In private, even in Communist times, most Czechs consistently preferred more emotive expressions such as srpnová okupace (the August occupation), sovertská okupace (the Soviet occupation), srpnová invaze (the August invasion) and sovětská invaze or sovětský vpád (the Soviet invasion). Janouch, for instance, in his account of the early days of normalization, is unambiguous about what he calls Príchod našich 'bratrü' s tanky (The arrival of our 'brothers' with tanks) - in one letter from 24 August 1968 he declares, 'Nenávidíme naše okupanty' (We hate our occcupiers); in another, written to a former teacher in the USSR on 15 October 1968, he notes 'Agrese zůstane agresí, okupace - okupací' (Aggression will remain aggression, occupation - occupation). ${ }^{69}$ While Janouch may have expressed the view of the majority of his compatriots, correspondence to the presenters of Czechoslovak television news, from 1968 and 1969, also appears to illustrate other perspectives. One anonymous joint letter reads: ' 23 years ago, and throughout the period of the Fascist

Future of Dissent in Czechoslovakia', Social Research, 57, 1990, 2, pp. 347-65, and Zdenko Pavelka, 'Jiřina Šiklová: Nepovažuju seza obět' ani za bojovnici', Právo, 17 November $2004<$ http://www.novinky.cz/kultura/43755-jirina-siklova-nepovazuju-se-za-obet-aniza-bojovnici.html $>$ [accessed 1 May 2012].

${ }^{68}$ See Richard S. Esbenshade's discussion of Kundera's contribution to this theme in 'Remembering to Forget: Memory, History, National Identity in Postwar East-Central Europe', Representations, 49, Special Issue: Identifying Histories: Eastern Europe Before and After 1989, (Winter) 1995, pp. $72-96$ (pp. 72-75). $31)$.

${ }^{69}$ František Janouch, Ne, nestěžuji se, Prague, 2008, pp. 21-22 (p. 22) and pp. 31-32 (p. 
occupation, for which "politicians and statesmen" of your type and nature were responsible, we all waited with longing for these soldiers from faraway and fraternal Russia. And today, you career-minded news presenters want to expel them. Never. ${ }^{30}$

In opposition circles, those who supported the intervention of the Warsaw Pact, especially signatories of the so-called zvaci dopis (invitation letter [to the Soviet leadership to intervene]), were often referred to by the most damning of Nazi-era descriptors - kolaboranti (collaborationists) and zrádci (traitors). The use of these terms to denote the very people who had so successfully exploited them for their own ideological purposes was a poignant testament to the erosion of the legitimacy of Communist rule. Nowadays, the 1968 intervention is formally known as invaze or vpád vojsk Varšavské smlouvy do Československa (the invasion of Czechoslovakia by Warsaw Pact troops), and invaze or vpád sovětských (okupačních) vojsk do Československa (the invasion of Czechoslovakia by Soviet [occupying] troops). The more neutral collocation sovětská intervence (Soviet intervention) is found just twice in SYN 2010 in relation to the events of 1968, whereas in the same context the citations for sovertská invaze/invase, S/srpnová invaze, S/sovětská okupace and S/srpnová okupace number thirty-nine, thirty-three, eighty-four and forty-three, respectively.

The use of okupace and its derivatives is one of the most historically significant examples of a composite name transfer. The noun okupace does not of itself give any indication as to the nature of the occupying force, but it invariably connotes an unwelcome intervention, and its strong associations with Nazism in a Czech context at the very least invite parallels with the German occupation. In the eyes of many Czechs and Slovaks, the Soviet soldier went from liberator to occupier in little more than twenty years, as reflected in the eight occurrences of the expression sovětští okupanti (Soviet occupiers) in SYN 2010. Yet, in fairness, it should be noted that the Red Army, which had been officially regarded as the most sacred of cows, never came to be seen privately, or (even in post-Communist times) publicly, as quite such a reviled beast as the Wehrmacht or, more so, the SS.

One of the salient features of Czechoslovak-Soviet relations was their constant transition both on an official (governmental) and a private level, frequently with a lack of correspondence between the two. The inherent instability and complexity of the interaction between the personal and the public was compounded by the fact that 'official' was a shifting

70 Jiří Svejkovský, Čas marných nadějí. Roky 1968 a 1969 ve zpravodajství ČST, Prague, 2010, p. 108. 
label, and by the ideological constraints imposed on the articulation and dissemination of the 'private'. Nevertheless, it is possible to present a somewhat crude overview of relations both from the perspective of the Czechoslovak state, on the evidence of historical studies and foreign policy initiatives, and of the majority individual viewpoint, on the basis of private correspondence and oral history. ${ }^{71}$ Officially, relations may be summarized as follows: guarded (in the First Republic) $>$ non-committal $(1938-41)>$ overtly hostile $(1941-45)>$ very positive $(1945-68)>$ guarded, but with strong support from hard-liners (Prague Spring) > very positive (postPrague Spring-1987) > guarded, with some tacit opposition to Gorbachev (1987-89) > non-committal, but cautious (1989-91). Privately, the schema is more complicated: mainly guarded, but with strong Communist support after 1921 (First Republic) > varied, but with some hope that the Soviet Union might eventually offer assistance (1938-41) > increasingly positive and hopeful of Soviet support (1941-45) > generally very positive, but with some reservations $(1945-48)>$ varied, with initial enthusiasm quickly and increasingly coloured by reality (1948-68) > guarded, and overtly hostile to the invasion (Prague Spring) > overtly hostile or indifferent (post-Prague Spring-1987) $>$ guarded, but with broad support for Gorbachev (1987-89) > non-committal, but cautious (1987-91). While the Czechoslovak-Soviet Pact of Friendship, Mutual Assistance and PostWar Cooperation (Československo-sovětská smlouva o prátelství, vzájemné pomoci a poválečné spolupráci), signed in Moscow in December 1943, may have offered hope for the future, the Pact of Friendship, Cooperation and Mutual Assistance between the ČSSR [Czechoslovak Socialist Republic] and the USSR (Smlouva o prátelství, spolupráci a vzájemné pomoci mezi ČSSR a SSSR), signed in May 1970, was greeted with apathy and disdain by most Czechs and Slovaks.

\section{Back to parliamentary democracy}

The political lexicon of the contemporary Czech state has been framed both by its Western democratic traditions and by its rejection of the abandonment of those traditions within the Soviet/Russian sphere of influence. The opportunity to present Communist excesses as a

${ }^{71}$ For a concise introduction to Czechoslovak-Russian/Soviet foreign relations, see Jindřich Dejmek, 'Vzestupy a pády politických utopií: Československo, Rusko a Sovětský svaz', in Československo, jeho sousedé a velmoci ve XX. Století (1918 až 1992), Prague, 2002, chapter 3, pp. 89-134. For an account of attitudes to life under Communism drawing on interviews with ordinary people, see Oldřich Tůma and Tomáš Vilímek, Opozice a společnost po roce 1948, Prague, 2009. 
deviation from Masarykian multi-party democracy and civilized Western norms greatly assisted the pro-democracy movement in its campaign to undermine the credibility of one-party rule. It is not without significance that the principal reformist slogans in November 1989 included Zpátky do Evropy (Back to Europe), Pro svobodnou republiku ve svobodné Evropě (For a free Republic in a free Europe) and Pravda a láska zvitězí nad lží a nenávistí (Truth and love will prevail over lies and hatred), referring to the mantra Pravda vitězi (Truth prevails), said to be derived from the words of Jan Hus, which has adorned the presidential standard since 1920. Such was the clamour in the early 1990 s to reinvent tradition and to reclaim the past that, in 1993, parliament passed a law, 'On the Illegality of the Communist Regime, and Resistance to It', which specifically condemned the Communist leadership and Party members for 'the systematic destruction of the traditional values of European civilization.? ${ }^{2}$

While interest in Masaryk's memory may have declined since the heydays of its revival in the Prague Spring and the early 1990s, phrases such as tradice prvni republiky (the traditions of the First Republic), období prvorepublikové demokracie (the period of First Republic democracy), předválečná demokracie (pre-war Czechoslovak democracy) and masarykovské dédictví (the Masaryk legacy) continue to have positive connotations for many ordinary Czechs. Politicians of various persuasions find it expedient to establish a link with this era, since it is felt to represent a golden age of Czech(oslovak) democracy, and suggests continuation along a path which was blocked by the unwelcome intervention of external forces. For instance, Langer has described the Civic Democratic Party (ODS) (a party which might be assumed to be politically to the right of Masaryk in some respects) as 'a liberal conservative party with a modern European structure, drawing on the traditions of mature Christian civilization, and on the humanitarian and democratic traditions of the First Republic and on the experiences of western democracies. ${ }^{73}$ While most parties are keen to identify with the best of the past, there is much more reluctance to engage with more thorny topics, such as the treatment of Czechoslovakia's minorities, and the expulsion of Germans and Hungarians after the war. Hence, there has been far from universal political endorsement of Havel's public apology to the Germans for their treatment in the so-called 'final

${ }^{72}$ See Ústav pro studium totalitních režimů, 'Zákon č. 198/1993 Sb., o protiprávnosti komunistického režimu a o odporu proti němu' <http://www.ustrcr.cz/data/pdf/normy/ sb198-1993.pdf> [accessed 28 April 2009].

73 Ivan Langer, ODS, no date $<$ http://www.langer.cz/texty.php?menu=71\&texty_id=23> [accessed 22 June 2010]. 
solution of the German question' (konečné řešení nèmecké otázky) another recycled phrase, calqued, not without sardonic irony, on German die Endlösung.

The transition to multi-party democracy is generally known by the phrase S/sametová revoluce (the Velvet Revolution) - a collocation which occurs 443 times in the 100-million-word corpus, SYN 2000, based mainly on texts from 1990 to 1999, and 350 times in SYN 2010. While revoluce is by some margin the most common collocate of S/sametovy in SYN 2010, and $S /$ sametovy is the second most common collocate of revoluce after $\mathrm{P} /$ po, sametová revoluce is by no means the only term used in Czech. SSČŠV (1994) also cites the synonyms L/listopadová revoluce (the November Revolution), which occurs sixty-six times in SYN 2010, and něžná revoluce (the Gentle Revolution), which is the norm in Slovak (nežná revolúcia), but is mentioned just twice in SYN 2010. ${ }^{74}$ Hlavsová has stated that (in the 1990 at least) Havel preferred the expression něžná revoluce, Klaus tended to use L/listopad 89 with a Czech audience (but sametová revoluce or its equivalent to a foreign audience), Wichterle employed prevrat, and Kroupa, in official contexts, would say pád totalitního režimu (the fall of the totalitarian regime). ${ }^{75}$ Another marginal alternative to sametová revoluce was plyšová revoluce (literally 'the Plush Revolution'), together with its colloquial derivative, plyšák. Whether reformers would have used terms such as revoluce and prevrat in the absence of the historical precedents of 1918 and 1948 remains a matter of conjecture, but the advantages of reappropriating these terms should not be underestimated.

The word revoluce, like prevrat, is something of a misnomer in the context of November 1989, in view of the peaceful nature of the overthrow of Communism, but its juxtaposition with sametová, něžná and plyšová is suitably striking. Fawn and Hochman suggest that even more common than any of the aforementioned phrases is the expression listopadové události (the events of November), although the evidence of SYN 2010, where it is cited twenty-four times, does not confirm this. ${ }^{76}$ Irrespective of its relative frequency, listopadové událost is important in the context of Czech historiography, since it both metaphorically and literally replaced únorové události, and its abridged form Únor, and subsequently srpnové

${ }^{74}$ Něžná revoluce is also the title of a film by Jiří Střecha and Petr Slavík (premièred in 1990, and translated into English as The Kind Revolution).

75 Jaroslava Hlavsová, 'Jazyk politiky', in František Daneš, Jarmila Bachmannová, Světla Čmejrková, Marie Krčmová (eds), Český jazyk na préelomu tisíciletí, Prague, 1997, pp. 26-41 (p. 30).

${ }^{76}$ Fawn and Hochman, Historical Dictionary of the Czech State, p. 269. 
události, in the pantheon of the 'great' dates, referred to by the names of months, that have changed the course of Czech society.

The last major landmark in Czech history - the split with Slovakia on 1 January 1993 - is not generally referred to by the month in which it occurred (perhaps because January had already been claimed in 1968), and has not generated many other memorable descriptors. One rhetorical phrase, however, stands out: sametový rozvod (velvet divorce), whose name, of course, owes its existence to sametová revoluce. While there is still a significant degree of regret over the dissolution of Czechoslovakia, the demise of state socialism has been much less lamented. Indeed, the period of Communist rule is summarily dismissed by most Czechs as an aberration and a disruption to historical continuity, for which the Soviet Union was largely responsible. Once again foreigners are thus charged with disrupting the 'organic' growth of the Czech nation. Granted, there remains relatively high support for the (largely unreconstructed) Communist Party of Bohemia and Moravia (KSČM) - 11.27 per cent in the May 2010 election - but its membership is ageing and generally marginalized. It is telling that even Czechs who see merits in the ancien régime rarely speak with enthusiasm about the USSR or Communist ideology, but instead highlight the relative equality of socialist society and the guarantee of certain basic provisions (such as housing, work, education and healthcare). Positive recollections of the socialist past are often tied to childhood and youth, and may be juxtaposed with life today under capitalism (or occasionally with stories of the economic hardships of the 1930 s and the war years). The collective memory of Communists tends to be fragmented and discordant, largely as a result of Stalinist repression and the post-1968 purges, and would appear to have limited direct impact on public discourse about the future direction of society. It inevitably excludes the younger generations, who have no practical experience of life under state socialism and are mainly acquainted through the media and education with the negative aspects of the system.

Many of the terms applied by Czechs to Communist rule have unambiguously critical connotations. Negative-sounding phrases which suggest a categorical rejection of the past include za bolševismu (under Bolshevism) or, more expressively, za bolševika (under the [government of the] Bolshevik), occasionally also za bolševikü (under the Bolsheviks), $z a$ komoušu (under the Commies), za soudruhü (under the comrades), and $v$ údobí totality/v totalitním údobí (in totalitarian times), $z a$ totalitního režimu (under the totalitarian regime) or, more colloquially, za totality 
and za totáče (under totalitarianism). Especially worthy of note is the relative frequency of use of the colloquial collocations $\mathrm{Z} / z a$ bolševika and $Z / z a$ totality, cited thirty-eight times and 163 times, respectively, in SYN 2010. Z/za totality is more common than its seemingly more neutral 'denotative' forms, Za/za socialismu (under socialism), cited 123 times, and $Z / z a$ komunistu (under the Communists), cited 135 times, as well as its historically less accurate synonym, Z/za komunismu (under Communism), cited 150 times. The stem T/totalit- (totalitar-) has 3,790 citations in the 100-million-word corpus, SYN 2000, whereas, by way of comparison, its English equivalent, T/totalitar- has 1,691 citations in the 450-million-word corpus, Bank of English, started in 1991 and last updated in 2002. ${ }^{77}$ (In relative terms, therefore, it is approximately ten times more common in Czech than English over a similar period.) As collocates of totalit- in SYN 200o, $z a$ and $Z a$ have t-scores of 12.9 and 5.065, respectively, in the range from -1 to o. The t-scores for $z a$ and $Z a$ as collocates of totalit- in SYN 2010 have changed little, at 12.01 and 4.057 , although the number of citations for T/totalit- has decreased by about 35 per cent to 2,445 .

The phrase $Z / z a$ komunistické totality (under Communist totalitarianism), which occurs five times in SYN 2010, is sometimes preferred for clarity, although nowadays $z a$ totality generally relates to Communist rule, unless context dictates otherwise. Paradoxically, the collocation is so fixed in the contemporary lexicon that it may be becoming, in a specific sense, partly desemanticized and routinized (that is, it may be losing some of its original pejorativeness, if not its points of reference). An unknown reader has helpfully described $z a$ totality as 'a good example of how emotive terms can become neutrally denotative, given time', and has drawn a comparison with the phrase 'Glorious revolution' in English history. Za totality quite deliberately suggests a non-nuanced approach to history, and is (not surprisingly, in view of its repeated use in relation to the German occupation) reminiscent of some of the cruder figurative devices of the socialist era. Not only does the expression treat the whole of the Communist period as a virtually seamless continuum, but it assumes a straightforward dichotomy between state socialism (or totalitarianism) and pluralism. Only occasionally do Czechs employ more finely differentiated alternatives such as za hluboké totality (under 'deep' totalitarianism) and za Husákovy totality (under Husák's totalitarianism).

Many other widely used lexical signposts also point to the failure of Communism, and intimate a strong degree of disapproval. Typical

77 The Bank of English <http://www.titania.bham.ac.uk/> [accessed 10 May 2011]. 
are expressions such as období komunistického teroru (the period of Communist terror [from 1948 to 1954, in particular]), bolševiáda (Bolshevik rule), bolševická diktatura (Bolshevik dictatorship), bolševická nadvládal hegemonie (Bolshevik hegemony), bolševická hrůzovláda (Bolshevik reign of terror), doba nesvobody, dobalúdobi totality (the period of totalitarianism), stará struktura (the old structures) and totalitní systém/režim (totalitarian system/regime). There are likewise many terms of pejoration used to denote people, groups and processes influenced by or associated with the former regime, such as polobolševik (semi-Bolshevik), polokomunista (semi-Communist), kryptokomunista (crypto-Communist), rebolševizace (rebolshevization), Rudé bratrstvo (the Red Brotherhood = the Communist Party) and státostrana (state party $=$ the pre-1989 Communist Party). Other lexical items explicitly linking the present to the Communist past have tended to indicate transformation relating to the decline in the Party's influence; for instance, debolševizace (debolshevization), polistopadový, postkomunistický (post-Communist) and posttotalitní (post-totalitarian).

Hard-line Communists may not have changed to the extent that they have in some other countries, but even they have had to engage, at least at some level, with the values of post-socialist society. They have also had to modify dramatically their use of lexical items which were previously at the core of their ideological repertoire, such as marxismus-leninismus (Marxism-Leninism), soudruh/soudružka (comrade) and třídní boj (the class struggle). The statutes of the KSČM, approved in 2008, refer to Marxist theory, but make no mention of Leninism, the class struggle or the leading role of the Party, and state their aim as the creation of 'socialism, a democratic society of free and equal citizens, a politically and economically pluralist society'. ${ }^{78}$ The term soudruh/soudružka, which originally denoted a 'work/social mate', was subject to permutation under Communism, but since 1989 it has become so stylistically coloured that it has virtually no neutral applications. As a mode of address, soudruhu/soudružko, formerly often preceded in the workplace by the greeting čest (práci) (honour [to labour]), is no longer generally used without irony (except perhaps in Communist Party meetings), and has been replaced by the norms of the pre-Communist era, pane/paní (Mr/Mrs), preceded by dobrý den (good morning/afternoon, hello). A more covert transition is also taking place in some of the less obviously politically motivated vocabulary; for example, $S /$ společenská vrstva (social class), cited 240 times in SYN 2010, is replacing S/ společenská třída, cited seventy-five times; D/dělnická třída (working class),

${ }^{78}$ See Úvodní stránka: Naše strana, Stanovy KSČM, 17 May $2008<$ http://www.kscm.cz/ index.asp?thema $=2677 \&$ category $=>$ [accessed 23 June 2010]. 
cited 292 times, increasingly relates to the realities of state socialism, and the concept pracujicí inteligence ('working intelligentsia'), cited nineteen times, has largely been confined to the status of an historicism.

A simple comparison of two of the buzzwords of the past, 'socialism' and 'Communism', illustrates how Stern's 'traditional range' (comprising the referential range and semantic range) has been affected by the change in the political system. Referential and semantic variation occurs both synchronically (especially official versus private) and diachronically (official versus private, and, after 1989, academic versus semi-official and private).

The first edition of SSČŠV (1978) defines socialismus as follows:

1. a socio-economic formation based on the collective ownership of the means of production; the first phase in the development of the social order [rád] established by the proletarian revolution (preceding Communism): to build socialism; the countries of socialism socialist states

2. scientific Marxist-Leninist teaching about the social order and its construction: scientific socialism

3. pre-Marxist teaching about the social order based on the nationalization [zespolečenštění] of property or generally aiming at a fairer social order: utopian socialism

4. the ideology of some political parties, movements etc. drawing on some elements of these teachings or misusing them: Indian socialism; (German) national socialism Nazism.

Particularly telling here is the emphasis on the scientific inevitability of the triumph of the Marxist-Leninist interpretation of socialism and the absence of any distinction between theory and practice. The second, post-Communist edition of the same dictionary, SSČŠV (1994), offers the following revised definition:

1. Marxism a socio-economic formation based on the collective ownership of the means of production: to build socialism; formerly the countries of socialism socialist states

2. teaching about the social order based on the nationalization of property or generally aiming at a fairer social order: utopian socialism

3. [as in 4. above].

Gone is any reference to Marxism-Leninism or to Communism, although the authors are happy to retain the phrase 'utopian socialism', which may 
have reflected a scepticism towards socialist solutions in general, shared by many Czechs at the time. By contrast, komunismus is defined in SSČŠV (1978) as:

1. classless society, the second phase of the social order after the victory of the proletarian revolution: transition from socialism to Communism

2. scientific Marxist-Leninist teachingabout thissociety and its construction: scientific Communism

3. pre-Marxist teaching aimed at social equality: utopian Communism

4. early [prvotní] Communism: primitive communal order.

Again Marxism-Leninism is the defining feature, whereas it is altogether absent in the illustration presented by SSČ $\breve{V}$ (1994):

1. economics joint ownership of property: the consumer Communism of religious sects

2. utopian forecasts of a socially just society; marxism social ownership of the means of production and remuneration according to needs

3. political and ideological theory and practice of Communist parties.

As the third definition of SSČŠV (1994) and the evidence of SYN 2010 show, most Czechs (excluding some historians and political scientists) have now largely embraced the Western definition of 'Communism' as a form of one-party socialism which promotes and implements policies (claimed by its supporters to have been) inspired by Marx and other revolutionary thinkers. This conceptual repositioning is reflected in a number of phrases commonly used to designate state socialism, such as komunistická éraléra komunistická (the Communist era), cited forty-seven times in SYN 2010, K/komunistická moc/moc komunistická (Communist power), cited sixtyeight times, and K/komunistický režim/režim komunistický (Communist regime), cited 817 times. Although these expressions are ostensibly neutral in tone, they are felt by many Czechs to denote a negative reality, which is confirmed and reinforced by the coexistence of some of the more obviously unflattering epithets referred to above, and by the prevalence of the concept of antikomunismus ('anti-Communism'), cited 111 times in SYN 2010.

An interesting article by Slačálek, inspired and assisted by Pavel Bareš, differentiates between 'distanční antikomunismus' (distancing antiCommunism [especially 1989-2002]) and 'vylučující antikomunismus' (excluding anti-Communism [especially after 2003]). The former, Slačálek 
says, was based on tolerance of the Communists, under the slogans nejsme jako oni (we're not like them) and Komunisté - zůstaňte doma (Communists - stay at home); the latter reflects the supposed threat posed by the unreformed KSČM, in the event of a realignment of the left which breaks with the 'hegemonic' anti-Communist consensus. ${ }^{79}$ The surprising resilience of the Communists and their legacy poses a particular problem to those on the centre-left of the political spectrum, especially the Czech Social Democratic Party (ČSSD), which would claim to be radically different to its former master, and is reluctant to be tarnished by association, but struggles without Communist support to build a working majority under the current proportional voting system. The dilemma of the ČSSD is yet another illustration of the fact that the collective memory of the past continues to exert a significant influence on the shape of contemporary Czech society. It is almost impossible to engage ideologically in the Czech Republic without reference to state socialism. In order to reject the past, and to hold it up as a warning to future generations, it is necessary to keep its memory alive (even if the very act of remembering may paradoxically sometimes make it harder to dissociate from the excesses of an earlier time).

\section{Conclusion}

In conclusion, it must be stressed that this article has focused on a phenomenon which is accentuated in a Czech context as a result of the particular geopolitical factors that have influenced the development of the nation state. The study does not claim that the notion of historical signposting is equally relevant to all societies, although it seems probable that, as a conceptual framework for interpreting diachronic change, it has applications beyond the Czech- (and Slovak-)speaking lands, especially in Eastern Europe. As far as I am aware, there has hitherto been no other research which has attempted to enumerate the characteristics of lexical signposts in Czech, or to focus on their usage in quite the same way or in as much depth. ${ }^{80}$ It may not be possible to quantify the extent of the ideological motivation involved in the specific types of 'composite name transfers' and other word forms identified, or to specify the range

79 Ondřej Slačálek, 'Český antikomunismus jako pokus o obnovu hegemonie', Britské listy, 22 June 2009 <http://www.blisty.cz/art/47533.html> [accessed 4 July 2010].

80 The term 'lexical signpost' has been employed in relation to other linguistic phenomena, such as orthography, and in contrast with the idea of the 'structural signpost'. See, for example, Francis Katamba, English Words: Structure, History, Usage, Oxford, 2005, p. 213, and Juan Carlos Acuña Fariña, 'On the Grammatical Status of "Colon Structures", Atlantis, 15, 1993, 1-2, pp. 5-20 (p. 16). 
of their subjective apprehension or the frequency of their occurrence in private communications. It has, however, proven possible, through detailed analysis of dictionaries and corpora, to give an indication of their official use and interpretation over time. The evidence presented here demonstrates that the terms in question derive at least some of their meaning from their juxtaposition with and appropriation of lexical items which have previously had different referents. In other words, they contribute to a semantic field which both reflects and redefines reality, and cannot therefore be adequately addressed merely through analysis of their potential or abstract meaning at a given point in time.

There are, of course, many factors other than ideological considerations which influence the expressions chosen to denote canonical events. These include the constraints imposed on usage by the limitations of the lexicon (especially the absence of pithy alternative mots justes), people's perceptions of the permissible semantic and referential range of existing terms, the appropriateness of stylistic register, linguistic fashion, and the possibility of 'substitution' (partial or complete borrowings from other languages and calques). It is unsurprising, for example, that preference is given in less formal conversation and correspondence to colloquialisms, such as za komoušu and androš ('undergrounder'), over more stylized and official-sounding phrases, such as $v$ područi bolševické hegemonie (under the yoke of Bolshevik hegemony) and príslušník undergroundu (member of the underground movement), respectively. It is equally unremarkable that several of the expressions cited, including doba nesvobody, have been applied to more than one type of authoritarian governance. What is, however, far more striking is the degree to which certain concepts, epithets and designations have become part of the metalanguage of contemporary discourse. The adoption and redefinition of so many existing temporal descriptors to indicate the ideological direction of the nation state would appear to be too systematic and calculated to be attributable merely to an insufficiency of viable alternative expressions. There seems to be a deliberate patterning to the representation of major historic turning points, which suggests a conscious desire both to update, and also to redraw, the historical map, by means of reference to the past. As the Party slogan says in George Orwell's Nineteen Eighty-Four: 'Who controls the past [...] controls the future: who controls the present controls the past. ${ }^{, 81}$

The repeated allusions to the First Republic, to Nazi rule and to state socialism confirm a strong desire to site present reality in the context of

${ }^{81}$ George Orwell, Nineteen Eighty-Four, in Peter Davison (ed.), The Complete Works of George Orwell, vol. 9, London, 1997, p. 37. 
former experiences. This tendency is especially transparent in some of the more marginal phrases such as masarykiáda (educational olympiad), hitlerjugend (today referring to young, unruly German tourists) and starstika - a compound neologism denoting 'dictatorship', which is comprised of svastika (swastika) and starý (komunistický režim) (old [Communist regime]). More significant, however, are the common, dynamic historical markers, such as prevrat, odboj, okupace and revoluce, and other expressions within the same or related semantic domains, which invite parallels with the past and simultaneously contribute to the formation of collective memory. The creation of a coherent national mythopoeia presupposes that the lessons of history be learnt and constantly reinforced, and that the lexicon be moulded to reflect the prevailing values of society. Hence, the title of Esbenshade's article (cited above, note 68), 'Remembering to Forget [...]', is well judged.

If this study has shed some light on the relations between a specific group of historical indicators, and on how and why their referential and semantic range has changed, it has achieved at least a part of its objective. If it has succeeded in showing that these terms constitute a specific semantic field, which functions both synchronically and diachronically, and operates differently on an official and a private level, it may have contributed a little more to lexical knowledge. 